\title{
INTEGRATING CHARACTER EDUCATION IN THE ENGLISH TEACHING AT ISLAMIC JUNIOR HIGH SCHOOLS IN INDONESIA
}

\author{
aA. Dzo'ul Milal, 'Zuliati Rohmah, 'Wahju Kusumajanti, \\ ${ }^{\mathrm{d}}$ Yazid Basthomi, ${ }^{\mathrm{e}}$ Diana Nur Sholihah, ${ }^{\mathrm{f}}$ Meinarni Susilowati \\ adzoulmilalfarchan@gmail.com, ${ }^{\mathbf{b}}$ zettira@gmail.com, \\ cwahjukusumajanti@uinsby.ac.id, dybasthomi@um.ac.id, \\ eadzkia87ar@gmail.com, ${ }^{\mathrm{f}}$ meinarni.susilowati@uin-malang.ac.id \\ ${ }^{a, b, c}$ UIN Sunan Ampel Surabaya \\ Jl. A. Yani 117, Surabaya \\ ${ }^{d}$ Universitas Negeri Malang \\ Jl. Semarang 5, Malang \\ ${ }^{e, f}$ UIN Maulana Malik Ibrahim Malang \\ Jl. Gajayana 50, Malang
}

\begin{abstract}
The rapid development of digital technology with its likely disruptive impacts on students' morality and character necessitates teachers to reorient their roles. Teachers need to be skillful in incorporating moral messages and character education in their teaching supported by suitable learning resources. The current research is conducted to fulfill the needs of the English teachers in Islamic junior secondary schools in Indonesia for supplementary materials that can support the integration of Islamic moral messages and values in the teaching of English. These needs were identified from data collected through questionnaires, FGDs, and interviews. The supplementary materials, which were designed based on the needs analysis, underwent expert validation and a pilot study. The final version of the materials consists of ready-to-use-worksheets and teacher's guide and is named the Islamic Life Resource Pack (ILRP).
\end{abstract}

Keywords: teacher roles, millennials, digital technology, character education, Islamic moral values, supplementary materials

DOI: http://dx.doi.org/10.15639/teflinjournal.v31i1/88-107 
The rapid development of digital technology has given birth to a generation called Generation Y (GenY), also known as millennials, born in 1980-1998 (Sutarna, 2018). These millennials are 'digital natives'; they are raised during the time when technology is integral to people's life (Corey, 2012). The most central experience for this group is the development of the Internet and digital technology, by which people are invariably associated with networks of individuals and data in ways that were previously impossible (Schoemaker, 2016). The Internet and digital technology could obviously support these digital natives to acquire new knowledge and skills. However, the negative impacts are also apparent and threatening. Young people these days might suffer from cyber bullying and be exposed to violent online games, pornography, hoaxes and scams, and other harmful contents through the Internet. In countering these, Gen Y should have "digital wisdom" (Prensky, 2008) which is a combination of their brains and advancement in digital technology and their ability to choose the right media, apply critical reading when receiving information, and maintain ethical values during the process. In the context of teaching and learning at schools, teachers need to apply procedures that will prepare students to acquire the skills needed to obtain comprehension, intuition and good judgment. Schools ought to prepare "digital citizens" by ensuring that teachers guide students in nine areas of conduct related to the employment of technology that comprise etiquette, communication, education, access, commerce, responsibility, rights, safety, and security (Ribble, Bailey \& Ross, 2004, p. 7).

One main implication of the rapid development of Internet and digital technology along with its possible harmful impacts is, therefore, the increasing importance of moral education. In terms of school contexts, it is essential that teachers guide their students to have strong beliefs, ethical values, cultures, wisdom as well as good characters. Teachers in the Industrial Revolution 4.0 need to be skillful in incorporating moral messages in their teaching in order to promote the good characters of the millennial students.

Character education (CE) has become the concern of the government of the Republic of Indonesia since 2010, especially through the Action Plan of National Character Education in 2010, and later on, Guidelines for Character Education 2011 (Puskurbuk, 2011) as well as Concepts and Guidelines for Strengthening Character Education (Kemdikbud RI, 2016). However, CE in Indonesia has not been successful due to several obstacles (Ash-Shiddiqi, 2018). Among the obstacles hampering the realization of $\mathrm{CE}$ include the 
inability of the school to select the appropriate values or characters to develop, teachers' lack of understanding of the concept of character education, the inability of the teachers to select the character values that fit into the subjects they teach, the lacking competence of the teachers in integrating character education in their teaching in the classrooms, and the failure of the subject teachers to be role models in the character building.

There are several studies that report on the implementation of $\mathrm{CE}$ in pesantren and Islamic schools in general, not specifically in the English classrooms (see, for instance, Anam, 2017; Dacholfany, 2015; Firdaus \& Wekke, 2018; Nuriman \& Fauzan, 2017; Rizal, 2014; Sutarna, 2018). However, both institutions are well-known for the practice of Islamic character education. What has not been widely reported is research that concerns the implementation of $\mathrm{CE}$ in the English classrooms through the integration of Islamic values.

In the context of English classrooms, the researchers found only Islami (2016) who conducted a study focusing on the internalization of character values in the English teaching and learning at an Islamic school in Samarinda. The report shows that the English teacher incorporates certain values and characters, such as, "independence, hardworking ethos, curiosity, democratic citizenship, communicative manner, and reading interest" in the process of English teaching and learning, but without deliberate intention. Therefore, the teacher does not evaluate whether the internalization of the good character is successful or not.

Any teaching and learning process should ideally be well-planned, fully executed and carefully evaluated. It is possible to thoroughly plan, execute and evaluate the integration of values in the English teaching. The purpose of integrating $\mathrm{CE}$ into English classroom is to provide a content-based environment for students to learn the language as well as the ethics (Tsui, 2008). Meanwhile, the growing interest in Content and Language Integrated Learning (CLIL) has resulted in excitement and active search for better methods of foreign language teaching (Cenoz et al., 2014). Thus, by incorporating moral values in the English classes, English teachers not only teach English for the sake of the language itself, but also introduce moral contents and inculcate the students with the values.

Therefore, the current research reports on the development of a learning package of Islamic contents to be used in English classes in Islamic school settings. This is to help the English teachers cultivate strong beliefs and good 
moral character among the students, especially in the context of Islamic schools. Using religious teaching to cultivate good character among the millennial generations is urgent as negative impacts of the technology have been felt in daily life, and broadcasted on the Internet as well as on television screens. This needs to be done in all subjects, including English.

Such religiously-based materials for English teaching are not easily available, particularly in the Indonesian context. Therefore, the English Language Teaching for Islamic School (ELTIS) Team, a team consisting of ELTIS management, master trainers, and advisers who have great concern on the quality of the English teaching Islamic schools, especially in the area of East Java, West Nusa Tenggara and South Sulawesi, conducted a needs analysis among Islamic Junior high school stakeholders (teachers, students and school principals) to identify the needs for the materials in more specifics. Based on the needs analysis, the team then designed supplementary materials to help the English teachers incorporate Islamic moral values into English teaching in the digital technology era. In addition to the needs analysis, in developing the materials the team members also consider the thirteen criteria used by Jahangard (2007) when evaluating materials, as follows: (1) Objectives should be made clear; (2) There should be good vocabulary explanation and practice; (3) Approaches should be educationally and socially acceptable to target community; (4) There should be periodic review and test sections; (5) There should be appropriate visual materials available; (6) Topics and tasks are interesting; (7) Instructions are clear; (8) Layout is attractive, print is easy to read; (9) Contents are clearly organized and graded; (10) There are plenty of authentic language items; (11) Grammar presentation and practice are good; (12) Fluency practices in all four skills are available; and (13) The materials should promote independent learning. The current paper describes the results of the needs analysis, materials development and validation processes, and the

end product named Islamic Life Resource Pack (ILRP) for use as supplementary materials in Islamic school context in Indonesia.

\section{METHOD}

Research and development (R\&D) design was applied in developing the ELTIS Islamic Life Resource Pack. The procedure was adapted from Borg, Gall, and Gall (2003, p. 570) and involved (1) needs analysis, (2) materials design and development, (3) expert validation (4) materials revision, (5) pilot 
study, and (6) second round of materials revision, and (7) final product dissemination.

Data regarding the needs for supplementary materials were obtained from questionnaires, focused group discussions (FGDs), and interviews. The questionnaires were completed by 187 English teachers in East Java and 193 English teachers in West Nusa Tenggara. The questionnaires mainly asked about the quality of the course-books utilized by the teachers when teaching students in Islamic junior high schools (MTs), class size, school facilities and supplementary materials. In assessing the quality of the course-books used in the English classes, the team used ten criteria (local criteria, cultural criteria, learning styles and learner autonomy, syllabus, methodology and learning principles, skills, instructions, physical characteristics, teacher guidance, and accuracy and naturalness of language model for learners). The respondents were asked to score the course book(s) they used in the classrooms in terms of each aspect. The score ranges from 1 to 5. Twelve questions about class size, school facilities and supplementary materials were formulated in the form of open-ended questions.

The FGDs gathered English teachers who joined the in-service teacher training conducted by ELTIS and who had at least two years of experience in teaching. There were two sessions of FGDs in East Java and two in West Nusa Tenggara with twenty-five participants in each session. Each session ended in 30-minutes guided by a member of the materials design team. The FGD discussed similar topics contained in the questionnaires. The FGD elaborated the questionnaire to collect more comprehensive information related to the sources of information utilized by the teachers and supplementary materials needed for the English classes.

Six MTs in East Java and seven MTs in West Nusa Tenggara were visited to conduct interviews with ten MTs principals, fifteen English teachers, and twenty-five voluntary students. From those schools, all principals were actually invited for the interviews but three of them were unavailable; one English teacher was expected to represent each school but two schools sent two teachers; and two students (one male and one female) from each school were called to the interview but one school sent only one student. The interviews with the principals were aimed at gathering information regarding classroom size, school facilities as well as their opinions regarding the English teaching in their schools. The interviews with the teachers focused on the course-books they use, the students' participation in the English classes and the 
supplementary materials they need to respond to the students' needs. The interviews with the students gathered information about the teaching techniques and activities their English teachers applied in the classrooms and their preference in learning English. The interviews were semi structured where the interviewers asked the already prepared questions and made notes on the responses from the interviewees. The interviews were conducted after the team obtained data from the questionnaires and the FGDs. Thus, the interviews were done to clarify some points and to strengthen the temporary conclusion made from the existing data.

The results of the needs analysis became the basis for developing the supplementary materials. The process of the material development involved two English lecturers from two-state Islamic universities, four English teachers from MTs in East Java and West Nusa Tenggara, and three native speakers of English. The lecturers and teachers were selected from among the master trainers based on their seniority and experience, and the native speakers were tutors of the trainings of the master trainers. Prior to the writing process, all members of the team discussed the results of the needs analysis and important principles they should apply in the writing process. During the process, each member was given a portion of material writing to be executed. When the design was completed, it underwent expert validation by a team consisting of three regional coordinators of the ELTIS project, and two invited English lecturers as expert validators. The review was conducted using an instrument designed to evaluate the quality of materials by focusing on important issues, that is, local criteria, cultural sensitivity, learning styles and learner autonomy, syllabus, methodology and learning principles, skills, instructions, physical characteristics (quality of the writing, layout and pictures), teacher guidance, accuracy and naturalness of language use, gender, environment, and health issues. Those points were elaborated into fifty-four statements which the validators should score from 1-5 and give comments on.

After the reviews were completed, the writing team consisting of native and non-native speakers revised the packs based on the reviewer comments. A pilot study was then conducted by trying out the materials in four Islamic junior high schools in Madura, East Java, where the majority of the respondents teach and two in West Nusa Tenggara. The team visited the schools and conducted a try out in three classes in each school. A master trainer involved in the writing of the materials tried out the materials by teaching the students in each school using the materials. This try out was observed by 
another member of the materials development team. The observation focused on suitability of the materials to the real situation in the classroom, effectiveness of the materials to be used in class activities, and the responses of the students to the materials. The results of the observations, combined with the teachers' and students' responses assessed at the end of the try out were then discussed by the materials development team members. Another revision was made after the try-out of the materials.

\section{FINDINGS AND DISCUSSION}

\section{Findings}

This section describes and discusses the results of the needs analysis, the process of design, pilot study and revision, and the end product of the supplementary materials.

\section{Needs Analysis}

There were four important findings from the needs analysis. The first identified need was that the supplementary materials for Islamic junior high schools should cater for big classes of up to 45 students that mostly have limited facilities, and provide a guide for the teachers. The second was that of the four language skills, the teachers, in particular, need resources to teach listening. The materials should include recorded materials that can be used by teachers to give models in pronunciation activities since many English teachers are not confident with their own articulation. The third point was that the materials should incorporate Islamic values. The fourth need was having fun activities while learning English by incorporating games, pictures, and songs in the supplementary materials. The last was the need of the stakeholders to help students prepare for the National Exam. The supplementary materials should consist of intensive activities to increase the students' confidence of their own ability to face the exam.

To respond to these needs, the ELTIS materials development team designed supplementary materials called ELTIS RESOURCE PACKS, which consist of Listening Resource Pack, Islamic Life Resource Pack, Games and Pictures Resource Pack, and Assessment Resource Pack. Since this article focused on character education, the article will only present the Islamic Life 
Resource Pack (ILRP) which was identified by the stakeholders as one of their needs.

\section{Materials Development, Pilot Study, and Revision}

In designing the Islamic Life Resource Pack (ILRP), the team first studied the basic competencies in the English syllabus of junior high schools and identified which of the competencies could possibly integrate Islamic messages and values. At this stage, the results of the need analysis and inputs from the stakeholders (students, school teachers, and principals) were taken into account and accommodated in the development of the materials. The writing of the contents also considered the practice of Islamic traditions and cultures in different parts of the world so that the students could have a broad horizon of Islamic culture. This is important to amplify students' tolerant character toward different practices of Islamic teaching in various parts of the world. As explained by Halstead (2007), there is a close link between morality and religion in Islamic thinking. There is no separate discipline of ethics in Islam. Moral education is about a spiritual matter that comes about through the internalization of comprehensive Islamic values and teaching.

The Islamic values were incorporated into the materials both directly and indirectly. Rohmah (2012, p. 160) explains that direct inclusion of Islamic values is discussing Islamic subject matters overtly. The ILRP contains some instances of this overt inclusion. For example, the chapters entitled "How to do wudhu" and "Muslim to Muslim", Islamic contents were explicitly integrated so that students can comprehend Islamic teaching while learning English. The chapter "How to do wudlu" can be used to teach procedure texts suggested by the English syllabus for junior high schools. On the other hand, an indirect inclusion of Islamic messages means putting the Islamic contents in the materials implicitly via photos, names, buildings, language activities, messages, and others.

Once the blueprint of the design was finished, the team started to write the materials, and the picture designer identified pictures and art products to prepare. The next step was inserting the pictures into the texts. The materials were then validated by experts. The results showed that the content coverage, writing quality, appropriateness with Islamic teaching and culture, quality of the design, and layout and pictures had fulfilled the expectation. All the invited experts considered those aspects of the materials to be of 'high quality'. One 
aspect that required improvement was related to gender awareness. The materials needed to include more examples to promote gender awareness in the forms of more balanced use of names of boys and girls, pictures of boys and girls, and fair activities of boys and girls. Inputs on some of the pictures were also given by the experts. Based on the evaluation by the experts, the design team then improved the materials.

After the materials were improved, a pilot study was conducted in schools involving students of four Islamic junior high schools in Madura, East Java, and two Islamic Junior high schools in West Nusa Tenggara. Based on the observation during the classroom tryout of the materials, it was found that most of the materials tried out were appropriate for the students' level, most of the stages of activities designed could be executed well, the twenty copies of the worksheets printed could be used to promote group or pair work very effectively, and the most important finding is that the students were very enthusiastic in learning since the activities were interesting and the worksheets were designed attractively completed with cute pictures. During the tryout, the students learnt the material 'How to do Wudlu' through 'Simon Says' game, which was modified into 'Fitri Says', and Total Physical Response (TPR). Through the learning activities, the students could give step-by-step instructions of how to do wudlu to their friends and follow the instructions given by their friends. The teachers involved also said that the material of 'How to do Wudlu' had opened up their mind that procedure text is not only limited to steps in cooking, but also many ritual activities in Islamic teaching. Some weaknesses of the materials were also identified during the tryout. For instance, certain vocabulary taken from Arabic word was not accompanied by the English equivalent (for example, the word wudlu). Some pictures were also found to be unsuitable to the contexts. Another issue was the difficulties felt by the teachers (including the master trainers who acted as the teachers) when teaching using the materials. Among the difficulties was in playing a game to start Unit 7 because the students did not have enough vocabulary to play the game. Based on the input given, more revision was then made to improve the quality of the materials.

\section{Islamic Life Resource Pack}

Once the second revision was finished, the resource packs were then disseminated, especially to teachers connected with ELTIS training in East Java, West Nusa Tenggara, and South Sulawesi as well as some other teacher 
training programs in various parts of Indonesia. Figure 1 shows the cover of the end product of the Islamic Life Resource Pack (ILRP) designed to facilitate the English teachers in Islamic junior high schools to incorporate Islamic messages in the teaching of English in the digital era.

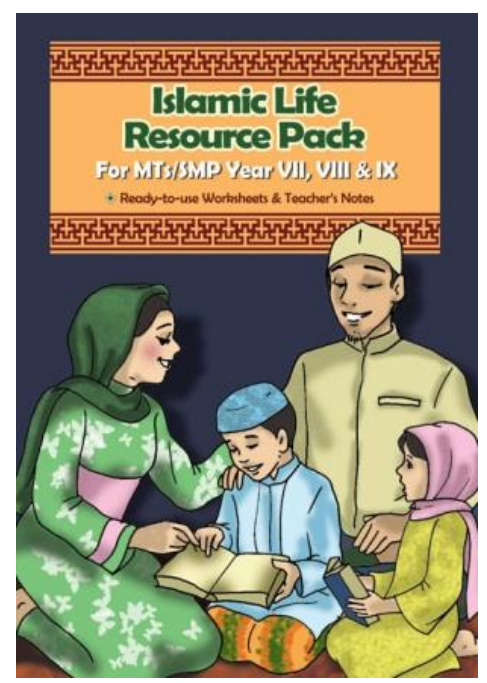

Figure 1. Islamic Life Resource Packs

The Islamic Life Resource Pack (ILRP) was developed to fulfill the demands of both MTs students and English teachers for supplementary materials containing Islamic values and teachings. The ILRP consists of worksheets for students accompanied with teacher's guide. The excellent design of the ILRP finalized with attractive pictures and visual decorations attract the millennial students to learn enthusiastically as apparent during the pilot project. The ILRP contains reading texts about Islamic routines and moral messages as well as some cross-cultural topics. Among the topics covered in the pack are email to a new Muslim friend, descriptive texts about famous Muslim public figure (the late Ustadz Jefri Al Buchori) and a Muslim family living in America, procedure texts to do wudlu (ablution) and to prepare banana kolak, a recount text of a healthy person, a biographical recount text of Muslim singers (Opik and Sulis), a narrative text containing moral messages (a merchant and his donkey), and several dialogues portraying good interactions 
that should be developed and nurtured by Muslims. Thus, the materials were developed to adapt to students' life in digital era

The twelve packages of worksheets were printed as many as twenty copies for each topic using thick paper with the size of half of A4-paper printed on both sides (see Figure 2). It accommodates the needs in big classes with the condition that each copy is shared for two or more students; hence, it could promote more collaborative learning. The worksheets were designed to be used many times because they were laminated, so the teachers do not need to copy the worksheets for each student every time they use them. Each worksheet contains exciting and stimulating activities appropriate for the students' stage and Islamic milieu.

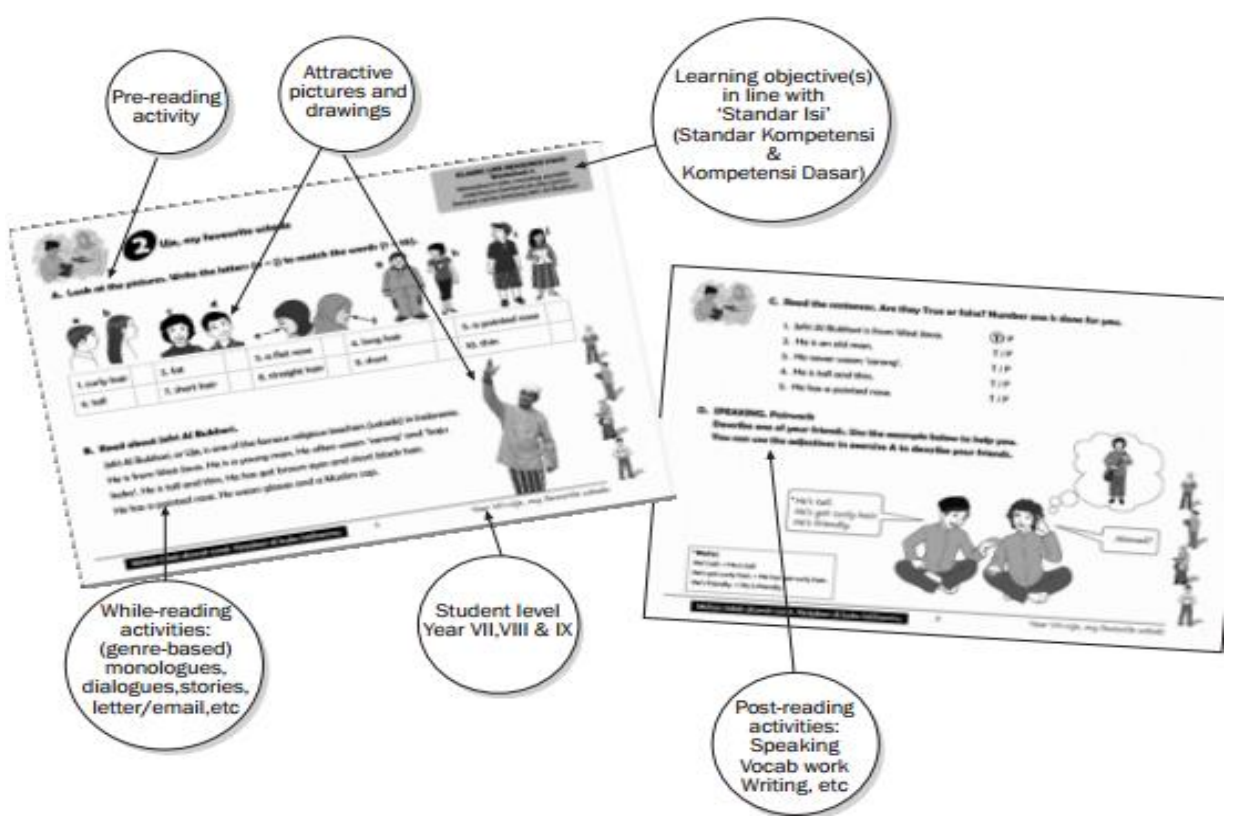

Figure 2. ILRP Worksheets

Among the important features in the worksheets are learning objectives, student level, pre-reading activities, while-reading activities in the forms of letter/email, stories, monologues, dialogues, etc., appealing pictures and drawings and post-reading activities in the forms of speaking activities, 
vocabulary work, writing activities and so on. As mentioned earlier, the integration of Islamic values and messages are done directly and indirectly in the materials; teachers may use the worksheets to inculcate the Islamic values and teaching through the readings texts available in the worksheets as well as various activities related to the tasks available in the worksheets. In Unit 8 (Can you keep the floor clean, please?), for example, the internalization of the attitude of loving cleanliness can be performed by learning vocabulary related to cleanliness (can be through games), practicing requests and responses to keep the environment clean (can also be done through various appropriate games and pair work), and performing various dialogues reflecting efforts in keeping cleanliness. At the end of the activities, the teacher may ask students to tell their daily activities to keep their homes and schools clean.

In addition to the worksheets, to help the English teachers use the ILRP in the classroom, the pack is also equipped with a Teacher's Guide. It consists of teacher's notes (Figure 3) and the corresponding contents of the worksheets printed in A4-size paper as well as a Phonemic symbol of English sounds with pictures and samples (see Figure 4).

The teacher's notes in the Teacher's Guide contain learning objectives, student level, suggested interaction pattern to make varied activities in the classroom, stages that are easy-to-follow and time-saving, classroom instructions to make teachers feel confident and to reduce teacher talking time (TTT) in the classroom, alternative activities to choose to suit real situations in the schools, answer key for the worksheets, and extended (follow up) activities, if time is available.

In the third column of the teacher's notes, teaching procedures consisting of step-by-step activities are listed. These contain easy-to-follow and time saving stages for busy teachers. The suggested teaching procedures were also completed with examples of short but clear instructions in the fourth column to make sure that the students could comprehend and emulate the teachers' language and respond to the instructions more easily. All these provide the teachers with a complete framework of teaching techniques that enable them to integrate Islamic values and messages while teaching the English language skills. 
100 TEFLIN Journal, Volume 31, Number 2, January 2020

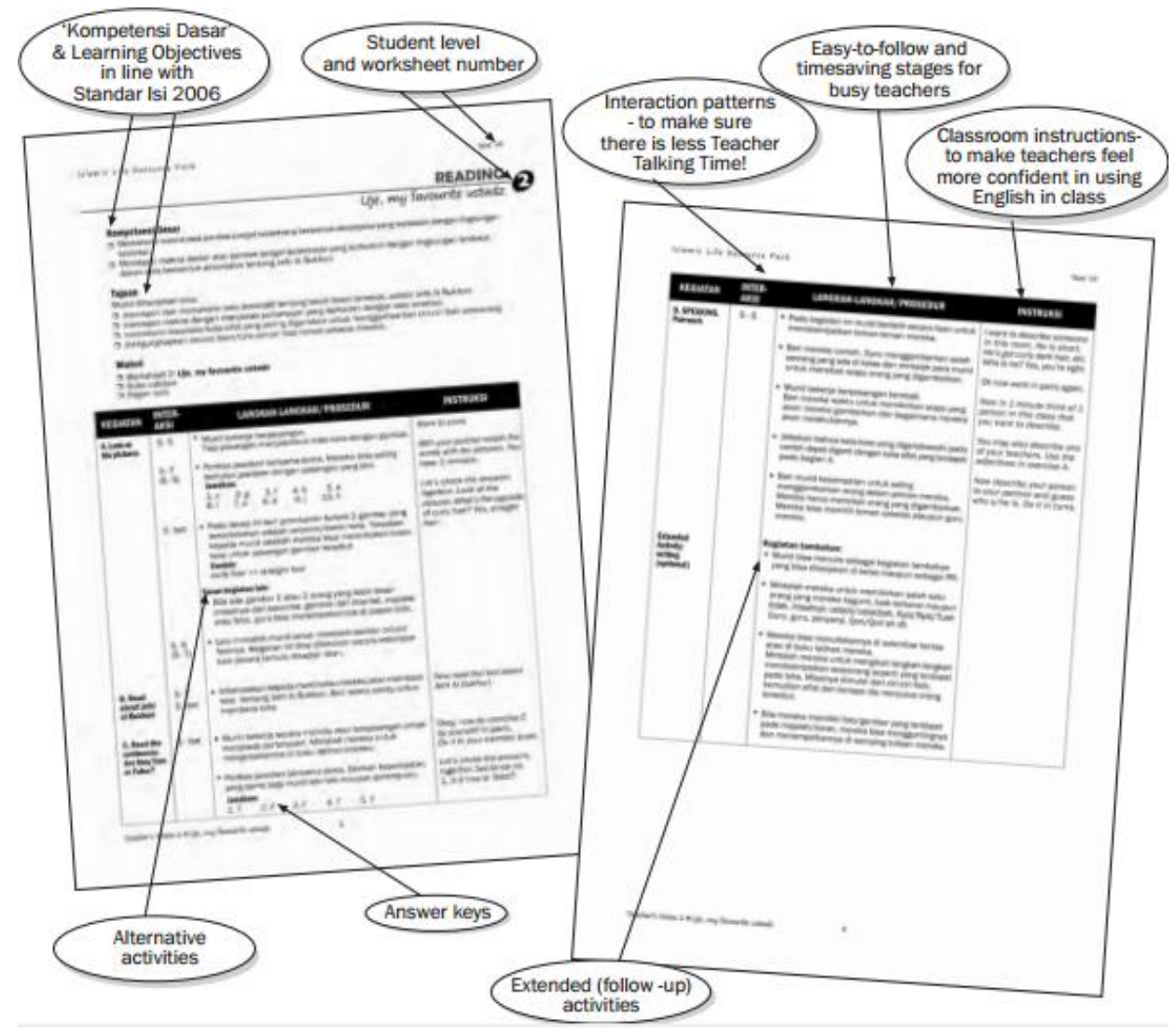

Figure 3. Teacher's Notes

In Figure 4, we can see the contents of worksheets put in the Teacher's Guide. The contents are exactly the same as those in Figure 2. The difference is that the worksheets in Figure 2 are printed separately on both sides of thick, laminated half A4 sized-paper and distributed for students' use in the classrooms. Meanwhile, the worksheet version contained in the Teacher's Guide is printed in full A4 sized-paper (see Figure 4) for the teachers' reference in planning, executing and evaluating the teaching-learning activities including the integration of Islamic moral values in the activities. 

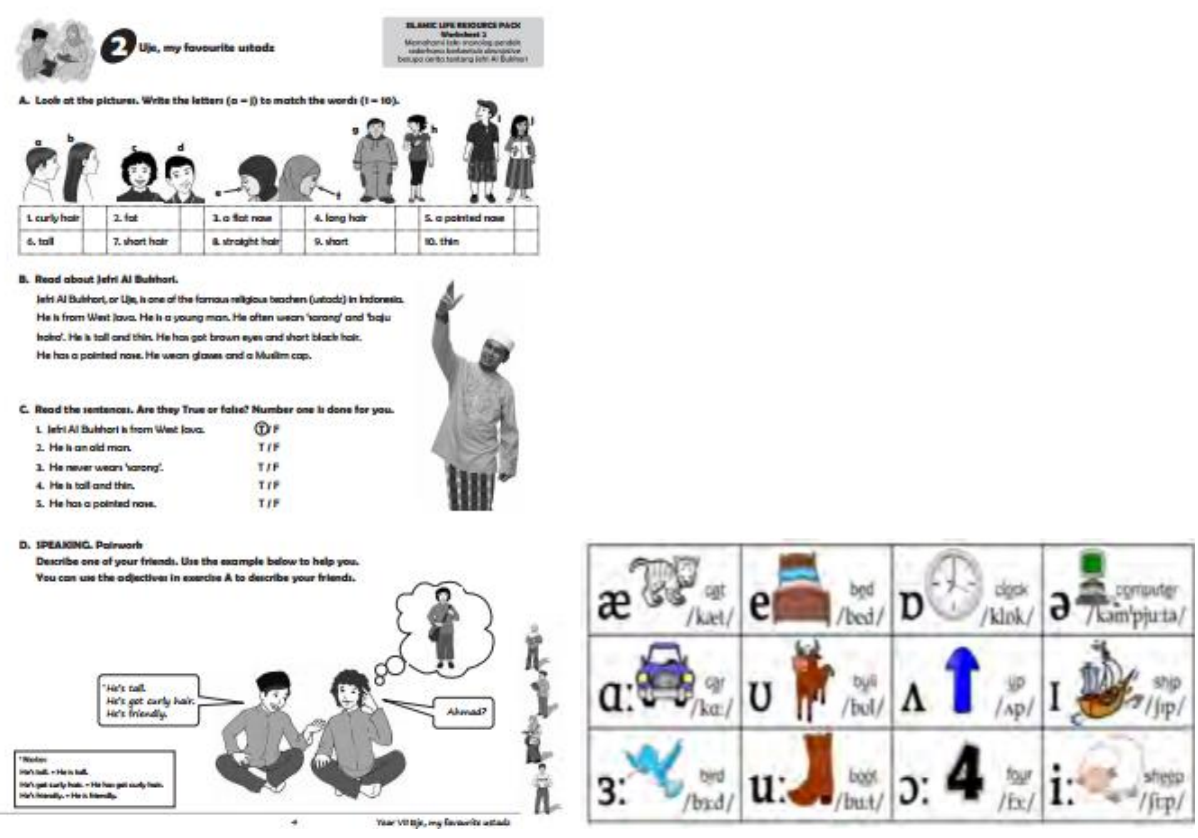

Figure 4. Worksheet Version in Teacher's Guide and Phonemic Chart

\section{Discussion}

The resource pack was developed based on the results of the needs analysis among the stakeholders in Islamic Junior High Schools. After being validated by experts, tried out at schools, revised by the design team and writers, the ILRP was distributed, especially but not limited to, Islamic junior high schools. Consisting of Teacher's Guide and worksheets which can be used during the teaching learning process, the ILRP promotes cooperative learning suitable for millennial students.

Cooperative learning, which has various benefits on the students' learning (Armadi, 2017; Kirbas, 2017; Mudiono, 2012; Poce et al., 2017; Rachmawati \& Asik, 2017; Ulya, 2016) is promoted in the ILRP by putting a variety of activities in the packs that enable students to learn and work together. The ILRP is equipped with ready-to-use worksheets to make sure that the English teachers can make use of the pack easily. They do not need to make a copy of the worksheets because they are printed with twenty copies. This situation also 
allows the students to use the worksheets while working in pairs or in groups. It is a good way to promote cooperative learning. The more able students can help the weaker students, and the less able students can learn from the stronger students.

The excellence of cooperative learning over traditional learning has been proven by a number of researchers focusing on ELT, for example, Alrayah (2018), Yavuz and Arslan (2018), and Atifnigar et al. (2020). Alrayah (2018), who conducted an experimental study in a university in Sudan, reported a statistically significant correlation between the Cooperative Learning activities and the improvement of EFL learners' oral fluency. Based on her findings, she made a recommendation directed to the authorities to coach EFL teachers in the application of Cooperative Learning activities in the English teaching/learning process.

Similar findings were also reported by Yavuz and Arslan (2018) from their quasi-experimental study of an English course at an Anatolian high school involving sixty-six tenth grade students. They discovered that cooperative learning had a larger effect on vocabulary knowledge, grammar, listening and reading skills compared to traditional method. Cooperative learning also has positive effects on the EFL learners in a university in Afghanistan. Atifnigar et al. (2020) found that cooperative learning has given a positive effect on the students' English speaking skills, enhanced their comprehension of the English language, and more importantly increased students' motivation and encouragement in acquiring English language skills.

In addition to the many benefits of Cooperative Learning obtained through the suggested activities of the ILRP, attractive pictures and drawings are also provided in the worksheets to attract students' motivation to learn. As millennials are more interested in visual aspects (Djiwandono, 2017), the ILRP is suitable materials for the GenY students. The world has developed into a visual-oriented platform. Relying on text alone to communicate a message does not work anymore. This group of individuals was perfectly positioned to become the earliest adopters of the world's most successful visual aspects (Valkama, 2015). By completing the worksheets with attractive visual images, the millennial students' learning can be further maximized.

Teacher's guide is provided in the pack because the data collected during the needs analysis show that the teachers expect more guidance for their teaching. With the guide, the teachers can make a lesson plan more easily and execute the lessons more efficiently. Teacher's guide help teachers to plan a 
lesson, provide thoughts to make the classroom activities alive and offer a variety of extra materials. Teacher's guide also enables teachers to give the students more activities to practice in the areas of the language they find thought-provoking. The teacher's guide also contains a complete framework of the teaching techniques, which is very helpful for the potentially difficult time, especially when the students' level of English is low and the school facilities are very limited.

The teacher's guide also provides suggested interaction patterns and classroom instructions to make sure that the teachers can give clear, concise instructions suitable for the already planned lesson stages. With this, the teacher is conditioned to talk less, and students talk more and have more time to practice speaking in the target language. It is essential since one crucial component of many modern ways of teaching is to lessen the amount of teacher talking time (TTT) as much as possible, to provide learners more opportunities to use the language (Kareema, 2014). Teachers need to reduce TTT for several reasons. The first is that too much TTT restricts the amount of STT (Students Talking Time); hence, it does not develop students' skills (Allwright,1982; Nunan, 1999). Second, a large amount of TTT results in long periods in teacher-to-class interaction and students who are not involved lose their concentration, get bored, and have lesser time for learning. Third, TTT also makes the teachers give the students information that they could obtain by themselves from various sources, including the Internet. Finally, if the teacher dominates and controls the class, the learners tend to have no initiatives for their own learning. Student autonomy is thus restricted. In short, too much TTT is not suitable for students in this era, the millennials (Kareema, 2014).

Unit titles in the ILRP, such as, 'Can you keep the floor clean, please?' and 'Daily activities,' are among the examples of the implicit integration of Islamic teaching in the resource pack. The use of Muslim names like Fatimah, Latifah, Luthfia, Umar, Ahmad, Azizah, Hakim, Ali, might better facilitate the Muslim learners to articulate their feelings better and more easily since they might think that their life and their friends are associated with the books. In the first unit, an email to Azizah, written by Anisa, gives an example of a Muslim's greeting to another Muslim. Muslim's names are also used to make students feel confident as Muslims since the names in the worksheet are the ones found in their daily life. Islamic music (nasyeed) is also mentioned to prevent students from feeling inferior with their own culture. The word 'boarding house' (worksheet 1 or page 1 of the Teacher's Guide) is used to name a 
building where many Muslim students live. These all help students express themselves more easily with proportional pride as Muslims. Guiding students to be proud of becoming Muslims and not to feel inferior when applying religious teaching and principles in daily life is an important part of CE based on Islamic moral education.

Having a strong moral value is very important for students in the digital era (Farisi, 2013; Huda et al., 2017). With more Islamic messages introduced to students in the rest of the pack, the students are expected to have an inclination to Islamic teaching and values while surfing in the unlimited world of information via the Internet. With a strong preference for Islamic values and character, the teacher can be confident that the students will be able to learn, unlearn, and relearn from digital technology appropriately. The millennial students will be able to choose which information to read, and once they read the information, they can opt whether to accept the information as something right or wrong - to decide to learn or unlearn from it. The students are also expected to respond to the information appropriately based on the Islamic values they have learned from the teachers.

\section{CONCLUSIONS}

The current paper describes supplementary materials to be used by English teachers in Islamic junior high schools to promote character education in Islamic school context. The supplementary materials are named The Islamic Life Resource Pack (ILRP) where Islamic moral values are incorporated in the English teaching materials. The accompanying teacher's guide helps teachers plan their lessons better and execute more effective teaching-learning process through various teaching techniques and clear instructions. This enables teachers to reduce TTT and provide more opportunities for students to polish their language skills. Last but not least, the ILRP contains Islamic messages which help teachers to inculcate good characters needed by students in this digital technology era. With their strong character, students will develop the required wisdom when encountering unclassified information available in the internet while at the same time enhancing their creativity and collaboration with others from different parts of the world. 
Milal et al., Integrating Character Education in English Teaching 105

\section{REFERENCES}

Allwright, R. L. (1982). 'What do we want teaching materials for?' ELT Journal, 36(1), 5-18.

Alrayah, H. (2018). The effectiveness of cooperative learning activities in enhancing EFL learners' fluency. English Language Teaching, 11(4), 2131.

Atifnigar, H., Zaheer, Z., \& Ayoubi, W. (2020). Exploring effects of cooperative learning among EFL learners in Laghman University of Afghanistan. SSRG International Journal of Humanities and Social Science, 7(2), 13-20.

Anam, S. (2017). Karakteristik dan sistem pendidikan Islam: Mengenal sejarah pesantren, surau dan meunasah di Indonesia [Characteristics and systems of Islamic education: Knowing the history of pesantren, surau and meunasah in Indonesia]. JALIE: Journal of Applied Linguistics and Islamic Education, 1(1), 146-167.

Armadi, S. (2017). Review efektifitas model cooperative learning dalam pembelajaran bahasa [Review of the effectiveness of cooperative learning models in language learning]. Cendekia: Jurnal Pendidikan dan Pembelajaran, 11(1), 117-128.

Ash-Shiddiqi, E. A. (2018). The analysis of character education in Indonesia. International Journal of Humanities, Art and Social Studies (IJHAS), 3(4), $39-46$.

Borg, W. R, Gall, M. D., \& Gall, J. P. (2003). Educational research (7th Ed). Longman.

Cenoz, J., Genese, F. \& Gorter, D. (2014). Critical Analysis of CLIL: Taking stock and looking forward. Applied Linguistics, 35(3), 243-262.

Corey, R. C. (2012). Digital immigrants teaching digital natives: A phenomenological study of higher education faculty perspectives of technology integration with English core content. (Unpublished Ed.D. Dissertation, Drake University, Des Moines, Iowa, USA).

Dacholfany, M. I. (2015). Reformasi pendidikan Islam dalam menghadapi era globalisasi: Sebuah tantangan dan harapan [Islamic education reform in facing globalization: A challenge and hope], Akademika, 20(1), 173-194.

Djiwandono, P. (2017). The learning styles of millennial generation in university: A study in Indonesian context. International Journal of Education, 10(1), 12-19. 
Farisi, M. (2013). Academic dishonesty in distance higher education: Challenges and models for moral education in the digital era. Turkish Online Journal of Distance Education, 14(4), 176-195.

Firdaus, \& Wekke, I. S., (2018). Pattern of character education at pesantren tarbiyah in West Sumatera, Indonesia. International Journal of Pure and Applied Mathematics, 119(18), 1023-1031.

Halstead, J. M. (2007). Islamic values: A distinctive framework for moral education? Journal of Moral Education, 36(3), 283-296.

Huda, M., Siregar, M., Ramlan, Matteh, K. S., Said, H., Jamsari, E. A., Rahman, S. K., Yacub, J. Dacholfany, M. I., \& Ninsiana, W. (2017). From live interaction to virtual interaction: Addressing moral engagement in the digital era. Journal of Theoretical and Applied Information Technology, 95(19), 4964-4972.

Islami, M. (2016). Character values and their internalization in teaching and learning English at madrasah. Dinamika Ilmu, 16(2), 279-289.

Jahangard, A. (2007). Evaluation of EFL materials taught at Iranian public high schools. Asian EFL Journal, 9(2), 130-150.

Kareema, F. (2014). Increasing student talk time in the ESL classroom: An investigation of teacher talk time and student talk time. Proceedings of the 4th International Symposium South Eastern University of Sri Lanka (SEUSL). Oluvil: SEUS.

Kementerian Pendidikan dan Kebudayaan (Kemdikbud) RI. (2016). Konsep dan pedoman penguatan pendidikan karakter [Concepts and guidelines for strengthening character education]. Jakarta: Kementerian Pendidikan dan Kebudayaan RI

Kirbas, A. (2017). Effects of cooperative learning method on the development of listening comprehension and listening skills. International Journal of Languages'Education and Teaching, 5(1), 1-17.

Mudiono, A. (2012). Peningkatan keterampilan menulis narasi melalui model cooperative integreted reading and composition di sekolah dasar [Improving narrative writing skills through a cooperative model of integrated reading and composition in elementary schools]. Retorika, 8(1), $1-8$.

Nunan, D. (1999). Second language teaching and learning. New York: Heinle and Heinle.

Nuriman \& Fauzan. (2017). The influence of Islamic moral values on the students' behavior in Aceh. Dinamika Ilmu, 17(2), 275-290. 
Poce, A., Agrusti, F., \& Re, M. R. (2017). Enhancing higher education students' $21^{\text {st }}$ century skills through co-writing activities in science teaching. Journal of E-Learning and Knowledge Society, 13(1), 27-40.

Prensky, M. (2008). The role of technology. Education Technology, (Nov-Dec 2008), 1-3.

Pusat Kurikulum dan Perbukuan (Puskurbuk). (2011). Pedoman pelaksanaan pendidikan karakter [Guidelines on the implementation of character education]. Jakarta: Puskurbuk, Kemdiknas.

Rachmawati, S. E. \& Asik, N. (2017). Teaching vocabulary through cooperative learning method at Islamic boarding school. Eternal, 3(2), 173-182.

Ribble, M. S., Bailey, G. D. \& Ross, T. W. (2004). Digital citizenship: Addressing appropriate technology behavior. Learning \& Leading with Technology, 32(1), 6-12.

Rizal, S. (2014). Developing a model of Islamic educational studies based reading comprehension instructional material through schema theory. Proceedings of Seminar on English Language Teaching (SELT) 2, 402408. Padang: UNP.

Rohmah, Z. (2012). Incorporating Islamic messages in the English teaching in the Indonesian context. International J. Soc. Sci. \& Education, 2(2), 157165.

Sutarna, N. (2018). Strengthening character education based on Islam for millennial generation in digital era. Proceedings of the 3rd International Conference on Education, 221-228. Batusangkar: IAIN Batusangkar.

Tsui, C. F. (2008). Character education in demand for the university EFL classroom. Foreign Language Study, 8(6), 85-101.

Valkama, S. (2015) The news consumption of digital natives. (Unpublished Master's thesis, University of Jyväskylä, Jyväskylä, Finland). Retrieved from https://jyx.jyu.fi/handle/123456789/48373

Yavuz, O., \& Arslan, A. (2018). Cooperative learning in acquisition of the English language skills. European Journal of Educational Research, 7(3), 591-600. 